\title{
Role of endogenous nitric oxide in airway microvascular leakage induced by inflammatory mediators
}

\author{
N. Kageyama, M. Miura, M. Ichinose, M. Tomaki, \\ J. Ishikawa, Y. Ohuchi, N. Endoh, K. Shirato
}

Role of endogenous nitric oxide in airway microvascular leakage induced by inflammatory mediators. N. Kageyama, M. Miura, M. Ichinose, M. Tomaki, J. Ishikawa, Y. Ohuchi, N. Endoh, K. Shirato. @ERS Journals Ltd 1997.

ABSTRACT: This study examines the role of endogenous nitric oxide (NO) in airway microvascular leakage induced by inflammatory mediators, which play an important role in asthmatic airways.

Guinea-pigs were anaesthetized and mechanically-ventilated with monitoring of arterial blood pressure, and airway microvascular leakage induced by intravenous injection of substance $P(S P)$, leukotriene $D_{4}\left(L_{T D}\right)$ and histamine was evaluated using Evans blue dye and Monastral blue dye in the presence and absence of the

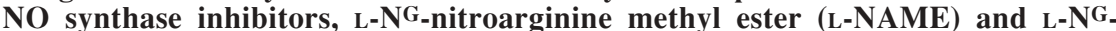
monomethyl arginine (L-NMMA). The effect of a soluble guanylate cyclase inhibitor, LY83583, on SP-induced dye leakage was also examined.

Intravenous injection of SP $\left(1 \mu \mathrm{g} \cdot \mathrm{kg}^{-1}\right), \mathrm{LTD}_{4}\left(1 \mu \mathrm{g} \cdot \mathrm{kg}^{-1}\right)$ and histamine $(100$ ug.kg-1) significantly increased dye extravasation at all airway levels. Pretreatment with L-NAME $\left(10 \mathrm{mg} \cdot \mathrm{kg}^{-1} i . v\right.$. $)$ and L-NMMA $\left(100 \mathrm{mg} \cdot \mathrm{kg}^{-1} i . v\right.$. $)$ significantly inhibited SP-induced extravasation, and L-arginine $\left(100 \mathrm{mg}^{-\mathrm{kg}^{-1}} i . v\right.$. $)$ reversed L-NAMEinduced inhibition. L-NAME $\left(10 \mathrm{mg} \cdot \mathrm{kg}^{-1} i\right.$.v. $)$ also significantly inhibited $\mathrm{LTD}_{4}$-induced dye extravasation only in central airways, and this inhibitory effect was abolished by a neurokinin-1 $\left(\mathrm{NK}_{1}\right)$ antagonist, $\mathrm{FK888}\left(10 \mathrm{mg} \cdot \mathrm{kg}^{-1} i . v\right.$.) pretreatment. Histamineinduced dye extravasation was not affected by L-NAME. LY83583 (2.5 and 7.5 $\mathrm{mg} \cdot \mathrm{kg}^{-1} i . v$.) partially but significantly reduced SP-induced dye leakage.

These results suggest that endogenous nitric oxide plays a role in neurokinin-1 receptor-mediated airway microvascular leakage, and presumably involves the guanylate cyclase pathway.

Eur Respir J., 1997; 10: 13-19.
First Dept of Internal Medicine, Tohoku University School of Medicine, Sendai, Japan.

Correspondence: K. Shirato

First Dept of Internal Medicine

Tohoku University School of Medicine 1-1 Seiryo-machi

Aoba-ku

Sendai $980-77$

Japan

Keywords: Airway plasma leakage leukotriene $\mathrm{D}_{4}$ neurokinin-1 receptor nitric oxide synthase inhibitor substance P

Received: January 181996 Accepted after revision July 31996
Microvascular leakage of protein-rich plasma is thought to be one of the inflammatory events in airway diseases, such as bronchial asthma [1]. A variety of inflammatory mediators, including histamine, leukotrienes (LTs) and tachykinins, released from inflammatory cells and sensory nerves, are known to cause airway microvascular leakage [2], which may produce airway hyperresponsiveness to nonspecific stimuli via oedema formation in airway mucosa [3]. Recently, the site of hyperpermeability and the associated morphological changes have been clarified in rat trachea [4], but the precise mechanisms that induce hyperpermeability still remain to be elucidated.

Recent investigations concerning nitric oxide (NO) have revealed the role of this substance in vascular permeability. However, the regulatory role of $\mathrm{NO}$ in vascular permeability is controversial. NO can account for the biological activity of endothelium-derived relaxant factor (EDRF) and is involved in the regulation of vascular tone [5, 6]. EDRF itself decreases vascular permeability in bovine aortic endothelial monolayers [7]. The use of NO synthase (NOS) inhibitors has suggested the protective role of endogenous NO against basal vascular leakage through the inhibition of neu- trophil adherence to endothelial cells [8]. These reports suggest a protective role of NO against increase in vascular permeability, especially in basal nonstimulated conditions. In contrast, the role of NO in vascular permeability in a stimulated condition appears complicated, since conflicting results have also been reported. In rat skin $[9,10]$, hamster cheek pouch [11], and guinea-pig skin [12], endogenous NO has been reported to mediate microvascular permeability elicited by inflammatory mediators. In addition, Kuo et al. [13] have demonstrated that tachykinin-mediated neurogenic plasma exudation was abolished by a NOS inhibitor in guinea-pig airways.

Recently, we have demonstrated that antigen-induced plasma leakage is inhibited by a NOS inhibitor in sensitized guinea-pigs [14]. Thus, the aim of the present study is to examine the role of endogenous NO in airway microvascular leakage induced by major inflammatory mediators in airways, such as histamine, $\mathrm{LTD}_{4}$ and sub-

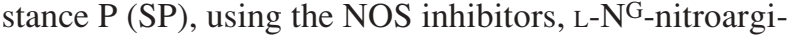
nine methyl ester (L-NAME) and $\mathrm{L}^{-\mathrm{N}^{G}}$-monomethyl arginine (L-NMMA). Furthermore, because many physiological functions of NO, including vascular smooth muscle relaxation, are dependent on cyclic guanosine monophosphate (cGMP) accumulation in the effector 
organs [15], using a soluble guanylate cyclase inhibitor, LY83583, we also examined whether the effect of endogenous NO in airway microvascular leakage involves cGMP production.

\section{Materials and methods}

\section{Animal preparation}

Male Dunkin-Hartley guinea-pigs (Funabashi Farm, Funabashi, Japan), weighing 350-400 g, were anaesthetized with urethane $\left(2 \mathrm{~g} \cdot \mathrm{kg}^{-1}\right.$ intraperitoneally) and placed on a thermostatically-controlled operation table (Model SN-622; Shinano Seisakusyo, Tokyo, Japan), which kept the animal's body temperature at around $37^{\circ} \mathrm{C}$. A tracheal cannula was inserted into the lumen of the cervical trachea through a tracheostomy, and the lungs were ventilated artificially with a small animal constant volume ventilator (Model SN-480-7; Shinano Seisakusho), at a frequency of 60 strokes $\mathrm{min}^{-1}$ and a tidal volume of 1 $\mathrm{mL} \cdot 100 \mathrm{~g}^{-1}$ body weight. A polyethylene catheter was inserted into the carotid artery to monitor blood pressure with a pressure transducer (P23 ID; Gould, Statham, USA). The jugular veins were cannulated for administration of intravenous drugs. All animals were pretreated with propranolol $\left(1 \mathrm{mg} \cdot \mathrm{kg}^{-1} \quad\right.$ i.v. $)$ and atropine $\left(1 \mathrm{mg} \cdot \mathrm{kg}^{-1}\right.$ i.v.) $30 \mathrm{~min}$ before experimentation to block the $\beta$ adrenergic and muscarinic modifications, respectively. All studies described here were conducted with the consent of the Ethics Committee for Use of Experimental Animals of the Tohoku University School of Medicine.

\section{Protocol}

In the first set of experiments, the effect of L-NAME $\left(10 \mathrm{mg} \cdot \mathrm{kg}^{-1}\right.$ i.v. $)$ and L-NMMA $\left(100 \mathrm{mg} \cdot \mathrm{kg}^{-1} i . v\right.$.) on SP $\left(1 \mu \mathrm{g} \cdot \mathrm{kg}^{-1} i . v.\right)$, and the effect of L-NAME $\left(10 \mathrm{mg} \cdot \mathrm{kg}^{-1}\right.$ i.v. $)$ on $\mathrm{LTD}_{4}\left(1 \mu \mathrm{g} \cdot \mathrm{kg}^{-1} i . v\right.$. $)$ or histamine $\left(100 \mu \mathrm{g} \cdot \mathrm{kg}^{-1}\right.$ i.v.) induced airway microvascular leakage was examined in order to elucidate the involvement of endognous NO in the responses. The doses of NOS inhibitor chosen here have been reported to produce submaximal inhibitory effects on endothelial NOS activity in vivo [16]. The doses of these mediators were chosen to obtain substantial dye extravasation to a similar degree among mediators. Firstly, NOS inhibitors or the vehicle (saline, $1 \mathrm{~mL} \cdot \mathrm{kg}^{-1}$ ) were administered intravenously. After obtaining a plateau increase in systemic blood pressure by NOS inhibitors at 4-6 min or after the same period of time had passed in the saline-treated group, Evans blue dye was injected $\left(30 \mathrm{mg} \cdot \mathrm{kg}^{-1} i . v\right.$.), followed by injection of each mediator 1 min later. In some animals of the SP group, L-arginine $\left(100 \mathrm{mg} \cdot \mathrm{kg}^{-1} i . v\right.$. $)$ was also administered at the peak time of the vasopressor response to L-NAME injection. In this case, SP was injected 2-3 min after the vasopressor response was reversed by $\mathrm{L}$-arginine. Using another group of animals, the effect of L-NAME $\left(10 \mathrm{mg} \cdot \mathrm{kg}^{-1}\right.$ i.v.) on basal plasma leakage was also examined.

In the second set of experiments, the effect of L-NAME on $\mathrm{LTD}_{4}$-induced airway microvascular leakage was again examined in the presence of $\mathrm{NK}_{1}$ receptor antagonist, FK888 [17], since a part of $\mathrm{LTD}_{4}$-induced airway plasma leakage is caused by $\mathrm{NK}_{1}$ receptor activation [18]. FK888 (10 mg. $\mathrm{kg}^{-1}$ i.v.) was administered after the vasopressor effect of L-NAME $\left(10 \mathrm{mg} \cdot \mathrm{kg}^{-1}\right)$ had reached a plateau and 1 min before Evans blue dye injection. The dose of FK888 was chosen according to our previous study [19].

In the third set of experiments, SP-induced airway microvascular leakage was examined in the presence or absence of a soluble guanylate cyclase inhibitor, LY83583, to determine whether the cGMP pathway is involved in the responses. LY83583 (2.5 or $7.5 \mathrm{mg} \cdot \mathrm{kg}^{-1}$ ) or the vehicle for LY83583, 75\% dimethyl sulphoxide (DMSO) $\left(0.1 \mathrm{~mL} \cdot \mathrm{kg}^{-1}\right)$, was administered intravenously 2 min before injection of Evans blue dye.

\section{Quantitative analysis of airway microvascular leakage}

Vascular permeability was quantified by the extravasation of Evans blue dye, which correlates well with the extravasation of radiolabelled albumin [20]. The dye was filtered using a $0.22 \mu \mathrm{m}$ Millipore filter (MILLEXGV, Millipore Products Division, Bedford, MA, USA) before use. The tissue content of Evans blue dye after experimental intervention was determined by perfusing the systemic circulation with saline to remove intravascular dye. Five minutes after the induction of leakage by mediator injection, the thorax was opened and a blunt-ended, 13-gauge needle was passed through a left ventriculotomy into the aorta. The ventricles were cross-clamped and blood was expelled through an incision in the right atrium with about $100 \mathrm{~mL}$ of saline at $100 \mathrm{mmHg}$ pressure until the perfusate was clear. The lungs were then removed. The connective tissues, vasculatures and parenchyma were gently scraped off, and the airways were divided into three components: lower part of the trachea (Tr), main bronchi (MB), and intrapulmonary airways (IPA). The tissues were blotted dry, placed in preweighed tubes, and reweighed, and their content was extracted in formamide at $37^{\circ} \mathrm{C}$ for $16 \mathrm{~h}$. The dye concentration was quantified from light absorbance at $620 \mathrm{~nm}$ by Labsystems Multiskan Bichromatic (Labsystems, Helsinki, Finland), and its tissue content (ng dye $\cdot \mathrm{mg}^{-1}$ tissue) was calculated from a standard curve of dye concentration in the range $0.5-10$ $\mu \mathrm{g} \cdot \mathrm{mL}^{-1}$.

\section{Histological demonstration of endothelial gaps}

Monastral blue dye is known to be extravasated from leaky vessels and trapped at endothelial gaps of these vessels [4]. Therefore, in order to localize and identify the sites of increased vascular permeability, Monastral blue dye (particle size of 5-200 nm) was used as a marker. Monastral blue dye was sonicated in an ultrasonic cleaner for $5 \mathrm{~min}$ and filtered using a $5 \mu \mathrm{m}$ Millipore filter. In this experiment, guinea-pigs were divided into three groups ( $\mathrm{n}=3$ each); 1) SP $\left(1 \mu \mathrm{g} \cdot \mathrm{kg}^{-1} i . v\right.$.) injection after saline $\left(1 \mathrm{~mL} \cdot \mathrm{kg}^{-1} i . v\right.$. $)$ pretreatment; 2$) \mathrm{SP}(1$ $\mu \mathrm{g} \cdot \mathrm{kg}^{-1} i . v$.) injection after L-NAME $\left(10 \mathrm{mg} \cdot \mathrm{kg}^{-1} i . v\right.$. $)$ pretreatment; 3) SP (1 $\mu \mathrm{g} \cdot \mathrm{kg}^{-1} i . v$. $)$ injection after L-NAME $\left(10 \mathrm{mg} \cdot \mathrm{kg}^{-1}\right.$ i.v. $)$ and $\mathrm{L}$-arginine $\left(100 \mathrm{mg} \cdot \mathrm{kg}^{-1} i . v\right.$. $)$ pretreatment. In all cases, Monastral blue dye $\left(30 \mathrm{mg} \cdot \mathrm{kg}^{-1}\right.$ i.v.) was injected (for $5 \mathrm{~s}$ ) immediately before the SP 
injection. A minute after the SP injection, the thorax was opened and the bronchial vasculature perfused with fixative (1\% paraformal-dehyde solution in phosphate-

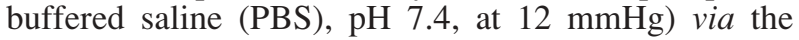
ascending aorta to remove the dye remaining within vessels. The trachea was then removed, opened longitudinally along the ventral midline, immersed in the same fixative for $2 \mathrm{~h}$ at $4^{\circ} \mathrm{C}$, and washed overnight in distilled water.

In order to prepare tracheal whole mounts, the tracheae were soaked in glycerol for $20 \mathrm{~h}$ at room temperature, followed by dehydration in $100 \%$ ethanol. Rehydrated tracheae were flattened between two glass slides held tightly by clips for $24 \mathrm{~h}$ in $100 \%$ ethanol, cleared in toluene for $15 \mathrm{~min}$, and mounted on glass slides for later light microscope processing.

\section{Drugs}

The following drugs were used: FK888, kindly donated by Fujisawa Pharmaceutical Co. Ltd (Osaka, Japan); SP and L-arginine (Peptide Institute Inc., Osaka, Japan); $\mathrm{LTD}_{4}$ (Cayman Chemical Co., Ann Arbor, MI, USA); LY83583 (BIOMOL Research Laboratories Inc., Plymouth Meeting, PA, USA); Evans blue dye and urethane (Aldrich Chemical Co. Inc., Milwaukee, WIS, USA); L-NG-nitroarginine methyl ester (L-NAME), L$\mathrm{NG}^{-}$-monomethyl arginine-acetate (L-NMMA), histamine dihydrochloride, formamide and dimethyl sulphoxide (Wako Pure Chemical Industries Ltd, Osaka, Japan); Monastral blue dye (Sigma Chemical Co., St Louis, MO, USA); propranolol hydrochloride (Imperial Chemical Industries plc., Macclesfield, UK); atropine sulphate (Tanabe Chemical Co., Osaka, Japan) and saline (Otsuka Chemical Co., Tokyo, Japan).

\section{Statistical analyses}

Data are expressed as mean \pm SEM. Comparisons of mean data among groups were performed by one-way analysis of variance (ANOVA) followed by Scheffe's test and Student's t-test for unpaired and paired data as post-hoc tests. Probability values of less than 0.05 were considered significant.

\section{Results}

\section{Effect of NOS inhibitors on SP-induced plasma leakage}

SP administration ( $1 \mu \mathrm{g} \cdot \mathrm{kg}^{-1}$ i.v.) caused substantial microvascular leakage of Evans blue dye at all airway levels, compared to guinea-pigs with saline administration (all $\mathrm{p}<0.01$, fig. 1$)$. L-NMMA (100 mg. $\mathrm{kg}^{-1}$ i.v.; $\mathrm{n}=$ 4) significantly inhibited SP-mediated responses in central airways. L-NAME $\left(10 \mathrm{mg} \cdot \mathrm{kg}^{-1}\right.$ i.v.; $\left.\mathrm{n}=5\right)$ more potently inhibited SP-mediated responses in all airway levels (fig. 1). Pretreatment with L-arginine $\left(100 \mathrm{mg} \cdot \mathrm{kg}^{-1}\right.$ i.v.) after L-NAME $\left(10 \mathrm{mg} \cdot \mathrm{kg}^{-1} i . v\right.$.) significantly reversed the L-NAME-induced reduction of plasma leakage (fig. 1). L-NAME (10 mg. $\mathrm{kg}^{-1} i . v$.) by itself had no significant effect on basal Evans blue dye extravasation.

The mean blood pressure in each SP-treated group is

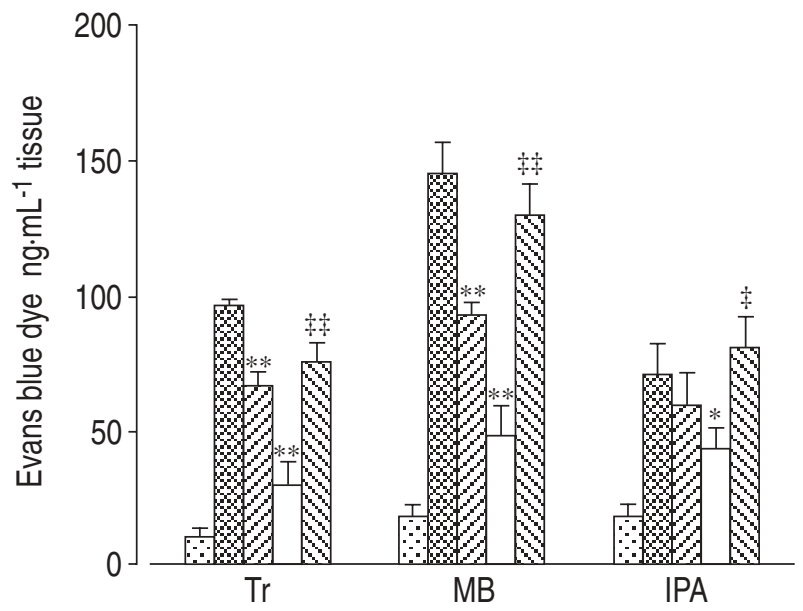

Fig. 1. - Effect of L-NG-nitroarginine methyl ester (L-NAME), L$\mathrm{NG}^{\mathrm{G}}$-monomethyl arginine (L-NMMA) and L-arginine (L-Arg) on substance P (SP)-induced microvascular leakage in guinea-pig airways. Saline pretreatment followed by SP administration $\left(1 \mu \mathrm{g} \cdot \mathrm{kg}^{-1} i . v\right.$.) produced significant dye extravasation ( $\$$ : saline + SP; $n=5$ ), compared with basal leakage $(\because \because$ : saline; $\mathrm{n}=5)$ (all levels $\mathrm{p}<0.01)$. Pretreatment with L-NMMA (100 mg. $\mathrm{kg}^{-1} i . v$.) (Z2: L-NMMA + SP); $\mathrm{n}=4)$ and with L-NAME $\left(10 \mathrm{mg} \cdot \mathrm{kg}^{-1}\right.$ i.v. $)(\square: \mathrm{L}-\mathrm{NAME}+\mathrm{SP} ; \mathrm{n}=5)$ reduced the SP-induced plasma leakage. The SP-induced plasma leakage was restored after co-pretreatment with $\mathrm{L}-\mathrm{NAME}\left(10 \mathrm{mg} \cdot \mathrm{kg}^{-1} i . v\right.$. $)$ and $\mathrm{L}-\mathrm{Arg}\left(100 \mathrm{mg} \cdot \mathrm{kg}^{-1}\right.$ i.v. $)$ ( $\left.\mathrm{S}: \mathrm{SP}+\mathrm{L}-\mathrm{NAME}+\mathrm{L}-\mathrm{Arg} ; \mathrm{n}=5\right)$. All values are mean \pm sEm. Tr: trachea; MB: main bronchi; IPA: intrapulmonary airways. *: $\mathrm{p}<0.05$; **: $\mathrm{p}<0.01$, compared with saline pretreated/SP treated group; $\ddagger$ : $<<0.05 ;+$; $\mathrm{p}<0.01$, compared with L-NAME pretreated group.

shown in table 1 . The mean blood pressure was significantly increased by L-NAME (by $32 \pm 5 \mathrm{mmHg}$ ), which was partly, but significantly, reversed by co-administration of L-arginine. L-NMMA also caused an increase in mean blood pressure (by $35 \pm 7 \mathrm{mmHg}$ ). Mean blood pressure after SP administration of the L-NAME and L-NMMA pretreated groups was not significantly different from the vehicle-treated group.

Histological demonstration of SP-induced plasma leakage

SP ( $1 \mu \mathrm{g} \cdot \mathrm{kg}^{-1}$ i.v.) induced Monastral blue extravasation in venular plexus within trachea (fig. 2a and b). Pretreatment with L-NAME $\left(10 \mathrm{mg} \cdot \mathrm{kg}^{-1} i . v\right.$. $)$ abolished this SP-induced Monastral blue extravasation, and no blood vessels were labelled by Monastral blue in these tissues (fig. $2 \mathrm{c}$ and d). The tracheal tissues taken

Table 1. - Blood pressure in SP-treated group

\begin{tabular}{lcccc}
\hline & Baseline & $\begin{array}{c}\text { Vehicle } \\
\text { or NOS } \\
\text { inhibitor }\end{array}$ & L-Arg & SP \\
\hline Vehicle (n=5) & $47 \pm 4$ & $47 \pm 4$ & & $29 \pm 2^{*}$ \\
L-NMMA (n=4) & $42 \pm 6$ & $77 \pm 9^{*}$ & & $22 \pm 2^{*}$ \\
L-NAME (n=5) & $41 \pm 2$ & $72 \pm 4^{*}$ & & $28 \pm 3^{*}$ \\
L-NAME + L-Arg & $33 \pm 4$ & $60 \pm 9^{*}$ & $43 \pm 4^{\dagger}$ & $17 \pm 2^{*}$ \\
$(\mathrm{n}=5)$ & & & &
\end{tabular}

Values are presented as mean \pm SEM. SP: substance P; L-NMMA; $\mathrm{L}-\mathrm{NG}^{\mathrm{G}}$-monomethyl arginine; L-NAME; $\mathrm{L}-\mathrm{N}^{\mathrm{G}}$-nitroarginine methyl ester; L-Arg: L-arginine. *: $\mathrm{p}<0.05$ vs baseline values; ${ }^{\dagger}$ : $\mathrm{p}<0.05$ vs L-NAME values. 

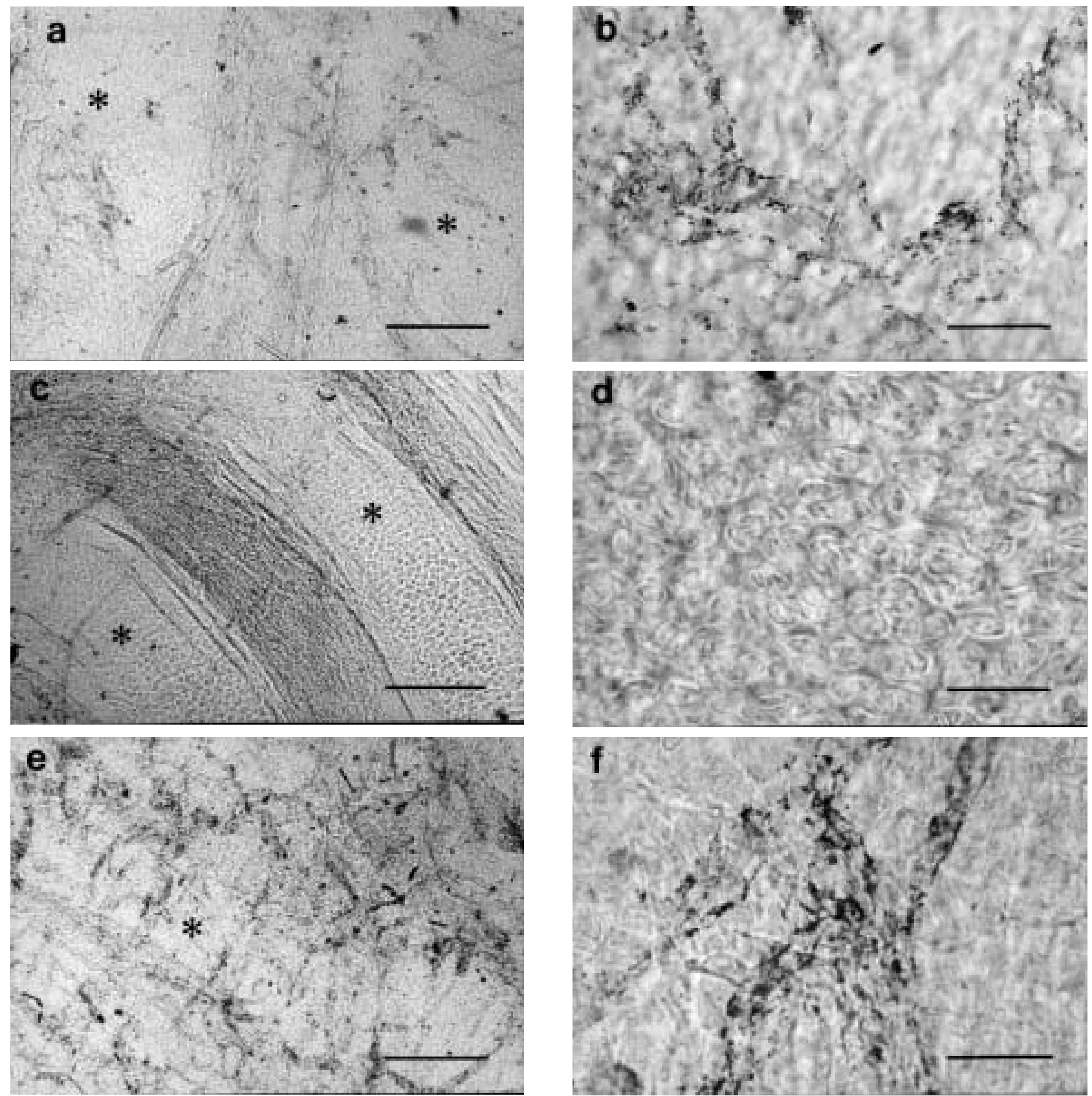

Fig. 2. - Low power field (a, c and e) and high power field (b, d and f) light micrographs of tracheal whole mounts of guinea-pigs. Substance $\mathrm{P}$ (SP), $1 \mu \mathrm{g} \cdot \mathrm{kg}^{-1}$ i.v., produced Monastral blue dye extravasation in the saline-pretreated guinea-pigs, and a relatively small number of venules

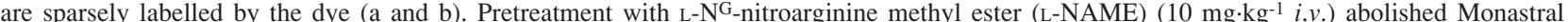
blue dye extravasation, and no venules were labelled by the dye (c and d). Co-administration of L-NAME (10 mg.kg-1 i.v.) and L-arginine (100 $\mathrm{mg} \cdot \mathrm{kg}^{-1}$ i.v.) potentiated Monastral blue dye extravasation, and a large number of venules are densely labelled by the dye (e and $\left.\mathrm{f}\right)$. (a, c and e: internal scale bar=250 um; b, d and f: internal scale bar=50 $\mu \mathrm{m})$. *: represent cartilagenous portion of trachea.

from the animals which received co-administration of L-NAME $\left(10 \mathrm{mg} \cdot \mathrm{kg}^{-1} i . v\right.$. $)$ and L-arginine $\left(100 \mathrm{mg} \cdot \mathrm{kg}^{-1}\right.$ i.v.) before SP injection showed prominent dye extravasation (fig. 2e and f), and the amount of extravasated dye in this group tended to be greater than that in saline pretreated group.

\section{Effect of L-NAME on LTD $_{4}$-induced plasma leakage}

$\mathrm{LTD}_{4}$ administration $\left(1 \mu \mathrm{g} \cdot \mathrm{kg}^{-1} i . v\right.$.) caused substantial airway microvascular leakage of Evans blue dye at all airway levels. L-NAME pretreatment $\left(10 \mathrm{mg} \cdot \mathrm{kg}^{-1}\right.$ i.v.) significantly inhibited $\mathrm{LTD}_{4}$-induced airway plasma leakage in trachea and MB but not in IPA (fig. 3a). The increase in blood pressure by L-NAME of the $\mathrm{LTD}_{4}$-administered group (by $33 \pm 4 \mathrm{mmHg}$ ) was not significantly different from that of the SP-administered group.

In the presence of $\mathrm{NK}_{1}$ receptor blockade by FK888 (10 mg.kg-1 i.v.), L-NAME pretreatment had no effect on the dye leakage induced by $\mathrm{LTD}_{4}$ (fig. 3b). Administration of FK888 itself had no effect on systemic blood pressure. 


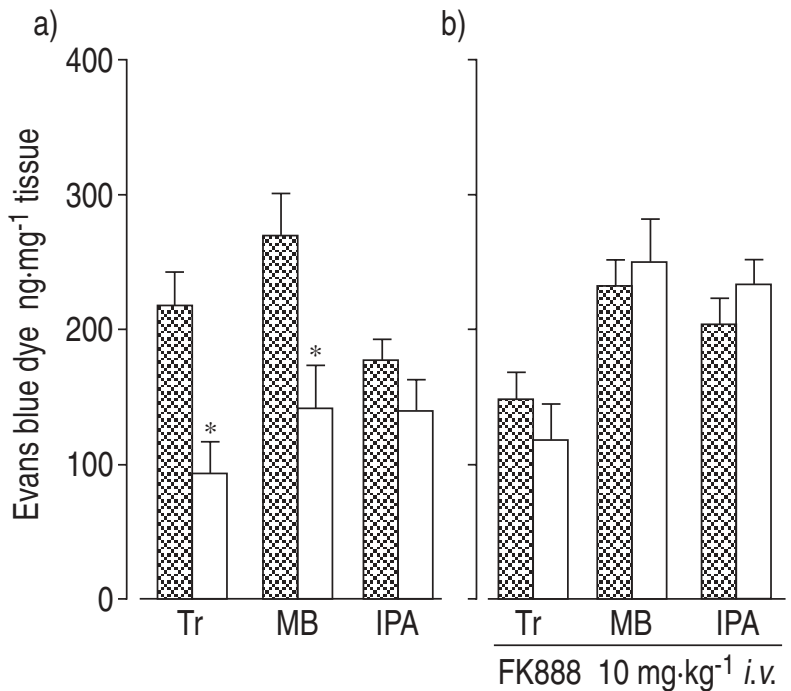

Fig. 3. - Effect of L-NAME on the $\mathrm{LTD}_{4}$-induced microvascular leakage: a) in the absence; and b) in the presence of the neurokin-1 $\left(\mathrm{NK}_{1}\right)$ receptor antagonist FK888 in guinea-pig airways. a) L-NAME pretreatment $\left(10 \mathrm{mg} \cdot \mathrm{kg}^{-1}\right.$ i.v. $)$ reduced $\mathrm{LTD}_{4}\left(1 \mu \mathrm{g} \cdot \mathrm{kg}^{-1} i . v\right.$. $)$-induced responses in central airways ( $\square$ : L-NAME $\left.+\mathrm{LTD}_{4} ; \mathrm{n}=4\right)$, compared with saline pretreatment ( $\$$ : $\left.\mathrm{LTD}_{4} ; \mathrm{n}=4\right)$. b) L-NAME pretreatment $\left(10 \mathrm{mg} \cdot \mathrm{kg}^{-1}\right.$ i.v.) had no significant effect on $\mathrm{LTD}_{4}$-induced microvascular leakage ( $\square$ : L-NAME + LTD 4 ; n=4) compared with saline pretreatment ( $\mathrm{Q}$ : saline $+\mathrm{LTD}_{4} ; \mathrm{n}=6$ ) in the presence of FK888 $\left(10 \mathrm{mg} \cdot \mathrm{kg}^{-1}\right.$ i.v. $)$. All values are mean \pm SEM. $*$ : $\mathrm{p}<0.05$, compared with $\mathrm{LTD}_{4}$ alone group. $\mathrm{LTD}_{4}$ : leukotriene $\mathrm{D}_{4}$. For further definitions see legend to figure 1 .

\section{Effect of L-NAME on histamine-induced plasma leak-} age

Histamine injection $\left(100 \mu \mathrm{g} \cdot \mathrm{kg}^{-1}\right.$ i.v. $)$ caused substantial microvascular leakage of Evans blue dye at all airway levels, which was not significantly affected by L-NAME pretreatment $\left(10 \mathrm{mg} \cdot \mathrm{kg}^{-1}\right.$ i.v.) (fig. 4). The mean increases in blood pressure by L-NAME of this group (by $33 \pm 9 \mathrm{mmHg}$ ) were not significantly different from those of the SP-administered group.

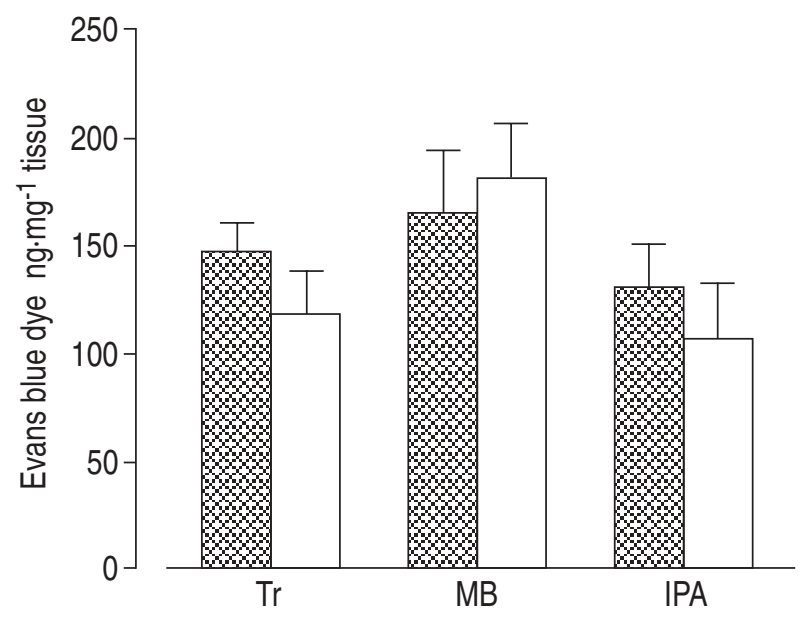

Fig. 4. - Effect of L-NAME on histamine-induced microvascular leakage in guinea-pig airways. L-NAME pretreatment $\left(10 \mathrm{mg} \cdot \mathrm{kg}^{-1} i . v\right.$. $)$ had no significant effect on histamine (HT; $100 \mu \mathrm{g} \cdot \mathrm{kg}^{-1} i . v$.)-induced microvascular leakage ( $\square$ : L-NAME + HT; $n=5)$, compared with saline pretreatment $(\boldsymbol{\infty}$ : saline $+\mathrm{HT} ; \mathrm{n}=5)$. All values are mean \pm SEM. For definitions see legend to figure 1.

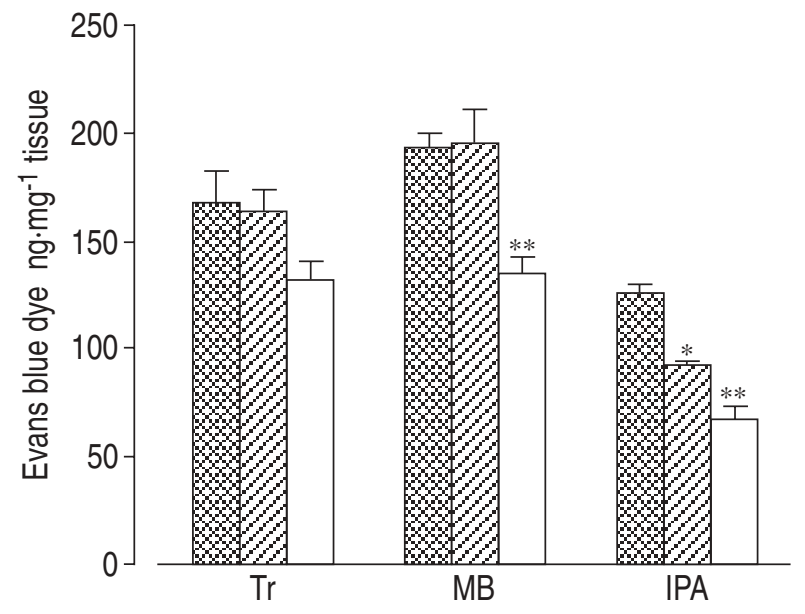

Fig. 5. - Effect of LY83583 on substance P (SP)-induced airway microvascular leakage. The closed columns indicate the response to SP $\left(1 \mu \mathrm{g} \cdot \mathrm{kg}^{-1}\right.$ i.v. $)$-induced airway microvascluar leakage after pretreatment with $75 \%$ DMSO ( $\propto$ : DMSO; $n=7$ ) was reduced by i.v. injection of 2.5 and $7.5 \mathrm{mg} \cdot \mathrm{kg}^{-1}$ of LY83583 pretreatment ( $Q$ : LY83583 $2.5 \mathrm{mg} \cdot \mathrm{kg}^{-1}(\mathrm{n}=3)$; and $\square$ : LY83583 $\left.7.5 \mathrm{mg} \cdot \mathrm{kg}^{-1}(\mathrm{n}=5)\right)$. All values are mean \pm SEM. DMSO: dimethyl sulphoxide. For further definitions see legend to figure $1 .{ }^{*}: \mathrm{p}<0.05$; $*^{*}: \mathrm{p}<0.01$, compared with DMSO group.

\section{Effect of LY83583 on SP-induced plasma leakage}

Intravenous injection of LY83583 (2.5 and $7.5 \mathrm{mg} \cdot \mathrm{kg}^{-1}$; $\mathrm{n}=3$ and $\mathrm{n}=5$, respectively) produced a transient increase in systemic blood pressure (from $27 \pm 4$ and $37 \pm 2$ to $53 \pm 7$ and $52 \pm 6 \mathrm{mmHg}$, respectively), which returned to the baseline values within 1 min. Pretreatment with LY83583 significantly inhibited SP-induced airway microvascular leakage dose-dependently in IPA, compared with the vehicle-treated (DMSO) group $(n=7)$. A higher dose of LY83583 also significantly reduced the dye extravasation in main bronchi, but not significantly in trachea (fig. 5).

\section{Discussion}

The present study demonstrated that NOS inhibitors, L-NAME and L-NMMA, inhibit SP-induced airway microvascular plasma leakage, and that the inhibition of SP-induced plasma leakage by L-NAME was significantly reversed by excessive administration of a substrate that generates NO, L-arginine. Therefore, endogenous $\mathrm{NO}$ is likely to participate in the responses. On the other hand, $\mathrm{LTD}_{4}$-induced plasma leakage was only partially inhibited by L-NAME, and histamine-induced leakage was unaffected. Thus, it seems that NO production is not necessarily a common pathway in the airway microvascular leakage induced by inflammatory mediators.

The inhibition of SP-induced plasma leakage by NOS inhibitors observed in the present study is possibly due to the vasoconstriction of perfusing vessels and the subsequent decrease in local blood flow at the leaky site, as has been suggested in guinea-pig skin [12]. Since both L-NAME and L-NMMA markedly increased systemic blood pressure in the present study, the perfusing blood volume within the bronchial circulation may have been decreased. Thus, the possibility that the reduction of bronchial blood flow by NOS inhibitors explains 
the results obtained cannot be excluded. On the other hand, it has been demonstrated that L-NMMA reduces the diameter of arterioles, but not that of venules, in hamster cheek pouch [21]. Because postcapillary venules are the sites of plasma leakage in the airway wall [4], the blood volume at the leaky sites still remains unchanged after administration of NOS inhibitor in guinea-pig airways. This allows the possibility that mechanisms other than the vasopressor actions of NOS inhibitors are also involved in the inhibition of SP-induced plasma leakage.

Airway plasma leakage is due to endothelial contraction and the resulting enlargement of the gaps in postcapillary venules, as supported by ultrastructural, pathological, and pharmacological studies $[1,4]$. Thus, NO may be directly involved in the process of airway plasma leakage via endothelial contraction at the leaky site. In the present study, Monastral blue dye was used as well as Evans blue dye to evaluate airway microvascular leakage. Monastral blue dye has been shown to extravasate only in abnormally permeable endothelium [22]. After extravasation, the dye is trapped at the basal lamina of the leaky vessels, so that endothelial gap formations can be identified by the labelling of the vessels with the dye. The fact that Monastral blue dye extravasation was abolished by L-NAME pretreatment and potentiated by co-administration of L-NAME and L-arginine supports the notion that endogenous NO is involved in the SP-induced endothelial gap formation of postcapillary venules. Indeed, there has been a report which suggests that SP generates NO in postcapillary venular cells [23].

$\mathrm{SP}$ is known to induce plasma leakage via $\mathrm{NK}_{1}$ receptors on endothelial cells in airways [24]. Thus, the present SP study suggests that $\mathrm{NK}_{1}$ receptor-mediated plasma leakage involves an endogenous NO production pathway. There are controversial reports about the role of NO in tachykinin-induced microvascular hyperpermeability in the airways. In rat airways, a NOS inhibitor, L-nitroarginine, has been reported to be without effect on $\mathrm{NK}_{1}$ receptor-mediated plasma protein extravasation [25]. In contrast, endogenous NO has been reported to play a role in the tachykinin-mediated neurogenic plasma exudation in guinea-pig airways [13], which is in agreement with our results. Although the discrepancy of the results between species is difficult to explain, the difference in the localization of NOS activities and/or intracellular signal transduction mechanisms after receptor activation might be possible reasons.

In the present $\mathrm{LTD}_{4}$ studies, L-NAME partially suppressed the induced plasma leakage in central airways, and this inhibitory effect disappeared in the presence of the $\mathrm{NK}_{1}$ receptor selective antagonist FK888 [17]. We have previously clarified the contribution of tachykinins to $\mathrm{LTD}_{4}$-induced plasma leakage in guinea-pig airways, in which FK888 and capsaicin pretreatment, which causes sensory neuropeptide depletion, partially inhibited the induced plasma leakage in central but not in peripheral airways [18]. This finding suggests that, in central airways but not in peripheral airways, $\mathrm{LTD}_{4}$-mediated airway plasma leakage is, in part, due to tachykinin release from sensory nerves. Thus, L-NAME seems to exert inhibitory effects against the $\mathrm{NK}_{1}$ receptor-mediated component of $\mathrm{LTD}_{4}$-induced plasma leakage. In contrast, histamine-induced plasma leakage was not affected by L-NAME. This result, in combination with that obtained from the $\mathrm{LTD}_{4}$ studies in the presence of the $\mathrm{NK}_{1}$ receptor antagonist, suggests that endogenous $\mathrm{NO}$ is not involved in the airway plasma leakage induced by the activation of histamine and LT receptors on endothelial cells.

NO is known to activate guanylate cyclase to accumulate cGMP in target organs, and this is one of the important signal transduction pathways in which NO is involved $[6,15]$. Indeed, NO has been reported to increase the cGMP level in bovine coronary postcapillary venular endothelial cells [22]. Bolus injection followed by continuous infusion of a soluble guanylate cyclase inhibitor, LY83583 [26], has been shown to decrease plasma cGMP levels and tissue cGMP contents [27]. In the present study, LY83583 reduced SP-induced airway plasma leakage especially in peripheral airways. This result indicates the involvement of cGMP production in SP-induced plasma leakage. cGMP by itself has been reported to suppress the basal level of plasma extravasation [28]. However, it is possible that an elevated cGMP level contributes to the plasma leakage by participating in the signal transduction after some kinds of receptor activation, as suggested in hamster cheek pouch [29].

In conclusion, we showed that endogenous nitric oxide is involved in neurokinin-1 receptor-mediated airway microvascular plasma leakage in guinea-pigs. Since a guanylate cyclase inhibitor, LY83583, significantly reduced neurokinin-1 receptor-mediated plasma leakage, this inhibitory effect of nitric oxide is thought to involve the cyclic guanosine monophosphate pathway. We have previously reported that neurokinin-1 receptor activation is involved in the airway plasma leakage induced by bradykinin [19], which is one of the important inflammatory mediators in airways [2], and that a tachykinin antagonist inhibits bradykinin-induced airway narrowing in asthmatic patients [30]. Thus, although the production of endogenous nitric oxide is not a common pathway in inflammatory mediator-induced airway plasma leakage, the role of nitric oxide as a proinflammatory mediator through neurokinin-1 receptor activation still appears important in airway inflammatory diseases, such as bronchial asthma [31].

Acknowledgement: The authors thank B. Bell for reading the manuscript.

\section{References}

1. Persson CGA. Plasma exudation and asthma. Lung 1988; 166: 1-23.

2. Barnes PJ, Chung KF, Page CP. Inflammatory mediators and asthma. Pharmacol Rev 1988; 40: 49-84.

3. Kimura $\mathrm{K}$, Inoue $\mathrm{H}$, Ichinose $\mathrm{M}$, et al. Bradykinin causes airway hyperresponsiveness and enhances maximal airway narrowing: role of microvascular leakage and airway edema. Am Rev Respir Dis 1992; 146: 13011305.

4. McDonald DM. Endothelial gaps and permeability of venules in rat tracheas exposed to inflammatory stimuli. Am J Physiol 1994; 266: L61-L83. 
5. Ignarro LJ. Biological actions and properties of endothelium-derived nitric oxide formed and released from artery and vein. Circ Res 1989; 65: 1-21.

6. Moncada S, Palmer RMJ, Higgs EA. Nitric oxide: physiology, pathophysiology and pharmacology. Pharmacol Rev 1991; 43: 109-142.

7. Oliver JA. Endothelium-derived relaxing factor contributes to the regulation of endothelial permeability. $J$ Cell Physiol 1992; 151: 506-511.

8. Kubes P, Granger DN. Nitric oxide modulates microvascular permeability. Am J Physiol 1992; 262 (Suppl. 31): H611-H615.

9. Hughes SR, Williams TJ, Brain SD. Evidence that endogenous nitric oxide modulates oedema formation induced by substance P. Eur J Pharmacol 1990; 191: 481-484.

10. Ialenti A, Ignaro A, Moncada S, Rosa MD. Modulation of acute inflammation by endogenous nitric oxide. Eur J Pharmacol 1992; 211: 177-182.

11. Mayhan WG. Role of nitric oxide in modulating permeability of hamster cheek pouch in response to adenosine 5'-diphosphate and bradykinin. Inflammation 1992; 16: 295-305.

12. Teixeira MM, Williams TJ, Hellewell PG. Role of prostaglandins and nitric oxide in acute inflammatory reactions in guinea-pig skin. $B r J$ Pharmacol 1993; 110: $1515-1521$.

13. Kuo H-P, Liu S, Barnes PJ. The effect of endogenous nitric oxide on neurogenic plasma exudation in guineapig airways. Eur J Pharmacol 1992; 221: 385-388.

14. Miura M, Ichinose M, Kageyama N, et al. Endogenous nitric oxide modifies antigen-induced microvascular leakage in sensitized guinea-pig airways. $J$ Allergy Clin Immunol 1996; 98: 144-151.

15. Moncada S, Higgs A. The L-arginine/nitric oxide pathway. $N$ Engl J Med 1992; 327: 511-515.

16. Rees DD, Palmer RMJ, Schulz R, Hodson HF, Moncada S. Characterization of three inhibitors of endothelial nitric oxide synthase in vitro and in vivo. BrJ Pharmacol 1990; 101: 746-752.

17. Fujii T, Murai M, Morimoto $\mathrm{H}$, et al. Pharmacological profile of a high affinity dipeptide $\mathrm{NK}_{1}$ receptor antagonist, FK888. Br J Pharmacol 1992; 107: 785-789.

18. Ishikawa $\mathrm{J}$, Ichinose $\mathrm{M}$, Miura $\mathrm{M}$, et al. Involvement of endogenous tachykinins in $\mathrm{LTD}_{4}$-induced airway responses. Eur Respir J 1996; 9: 486-492.

19. Nakajima N, Ichinose M, Takahashi T, et al. Bradykinininduced airway inflammation: contribution of sensory neuropeptides differs according to airway site. Am $J$ Respir Crit Care Med 1994; 149: 694-698.

20. Rogers DF, Boschetto P, Barnes PJ. Plasma exudation: correlation between Evans blue dye and radiolabeled albumin in guinea-pig airways in vivo. J Pharmacol Methods 1989; 21: 309-315.

21. Rees DD, Palmer RMJ, Moncada S. Nitric oxide and the microcirculation. In: Moncada S, Higgs EA, eds. Nitric oxide from L-arginine: a bioregulatory system. Amsterdam, Elsevier, 1990; pp. 427-437.

22. McDonald DM. Neurogenic inflammation in the rat trachea. J Neurocytol 1988; 17: 583-603.

23. Ziche M, Morbidelli L, Parenti A, Amerini S, Granger HJ, Maggi CA. Substance P increases cyclic GMP levels on coronary postcapillary venular endothelial cells. Life Sci 1993; 53: 229-234.

24. Hirayama Y, Lei Y-H, Barnes PJ, Rogers DF. Effects of two novel tachykinin antagonists, FK224 and FK888, on neurogenic airway plasma exudation, bronchoconstriction and systemic hypotension in guinea-pigs in vivo. Br J Pharmacol 1993; 108: 844-851.

25. Santicioli P, Giuliani S, Maggi CA. Failure of L-nitroarginine, a nitric oxide synthase inhibitor, to affect hypotension and plasma protein extravasation produced by tachykinin $\mathrm{NK}_{1}$ receptor activation in rats. J Auton Pharmacol 1993; 13: 193-199.

26. Mülsch A, Lückhoff A, Pohl U, Busse R, Bassenge E. LY83583 (6-anilino-5, 8-quinolinedione) blocks nitrovasodilator-induced cyclic GMP increases and inhibition of platelet activation. Naunyn Sch Arch Pharmacol 1989; 340: 119-125.

27. Brandt MA, Conrad KP. In vivo and in vitro studies of a putative inhibitor of cyclic guanosine 3',5'-monophosphate production. Proc Soc Exp Biol Med 1991; 196: 30-35.

28. Kubes P. Nitric oxide-induced microvascular permeability alterations: a regulatory role for cGMP. Am J Physiol 1992; 265: H1909-H1915.

29. Mayhan WG. Nitric oxide accounts for histamineinduced increases in macromolecular extravasation. $\mathrm{Am}$ J Physiol 1994; 266: H2369-H2373.

30. Ichinose M, Nakajima N, Takahashi T, Yamauchi H, Inoue $\mathrm{H}$, Takishima $\mathrm{T}$. Protection against bradykinininduced bronchoconstriction in asthmatic patients by neurokinin receptor antagonist. Lancet 1992; 340: 1248-1251.

31. McFadden ER, Gilbert IA. Asthma. $N$ Engl J Med 1992; 327: 1928-1937. 